九州大学学術情報リポジトリ

Kyushu University Institutional Repository

\title{
GLiricidia Tree Leaf Incorporation into Soil and Use of Companion Plants for Safe Tomato Production
}

BHUIYA, Mahfujul Islam

Department of Agroforestry and Environment, Faculty of Agriculture, Bangabandhu Sheikh Mujibur Rahman Agricultural University

RAHMAN, Md. Abiar

Department of Agroforestry and Environment, Faculty of Agriculture, Bangabandhu Sheikh Mujibur Rahman Agricultural University

MIAH, Md. Main Uddin

Department of Agroforestry and Environment, Faculty of Agriculture, Bangabandhu Sheikh Mujibur Rahman Agricultural University

AMIN, Md. Ruhul

Department of Entomology, Faculty of Agriculture, Bangabandhu Sheikh Mujibur Rahman Agricultural University

他

https://doi.org/10.5109/2558881

出版情報: 九州大学大学院農学研究院紀要. 65 (1)，pp.1-7，2020-02. Faculty of Agriculture， Kyushu University

バージョン :

権利関係 : 


\title{
Gliricidia Tree Leaf Incorporation into Soil and Use of Companion Plants for Safe Tomato Production
}

\author{
Mahfujul Islam BHUIYA ${ }^{1}$, Md. Abiar RAHMAN ${ }^{1, *}$, Md. Main Uddin MIAH ${ }^{1}$, \\ Md. Ruhul AMIN ${ }^{2}$, Satya Ranjan SAHA ${ }^{1}$ and Ikuo MIYAJIMA ${ }^{3}$
}

\author{
Institute of Tropical Agriculture, Kyushu University, \\ Fukuoka 819-0395, Japan \\ (Received September 17, 2019 and accepted November 14, 2019)
}

\begin{abstract}
Bangladeshi soils are generally low in fertility and enhanced crop yield is only possible through using of a combination of organic and inorganic fertilizers. Continuous use of agrochemicals in crop production and processing not only affecting the food quality, environment and humans but also increasing cost of production. A field study was conducted to investigate the effectiveness of companion plant (basil, nira and coriander) as an alternative pest management strategy along with application of organic matter (gliricidia tree leaf and cow dung) for safe tomato production, insect abundance and soil properties changes. Tomato yields were 59 and $61 \%$ higher when grown in gliricidia+basil plot compared to no-companion plant and noorganic matter treatment, respectively. Insect infestation was significantly lower in companion plant treatments. Soil pH and organic carbon were higher in cow dung than gliricidia leaf applied treatment. Results revealed that tomato in association with companion plants had potential effect on reducing insect pests as well as attracting pollinators and predators. However, the degree of potentiality of companion plants can be ranked as basil>coriander>nira. Therefore, tomato can be grown successfully in association with Basil as companion plant and by incorporating gliricidia tree leaf into soil as green manure.
\end{abstract}

Key words: Abundance, cow dung, diversity, insect, richness, soil properties.

\section{INTRODUCTION}

Among economically important vegetables, tomato (Solanum lycopersicum L.) is one of the world's most cultivated vegetables with a worldwide production of $177,042,359$ tons (FAO, 2018). It is consumed throughout the world and has been demonstrated to possess health benefits due to its high content of phytonutrients (Hsu et al., 2008). It is also important as a god source of vitamins, minerals and fiber in human diets. Due to adaptability to wide range of soil and climatic conditions, it is cultivated throughout the Bangladesh. Currently, the tomato growing area is around 27, 114 hectares, with annual production of 368,000 metric tons (Bangladesh Bureau of Statistics [BBS], 2017). The average yield is $13.46 \mathrm{mt} \mathrm{ha}^{-1}$ in Bangladesh (BBS, 2017) which is low compared to other countries like India (21.96 mt ha-1), Japan (55.72 mt ha ${ }^{-1}$ ), USA (81.91 $\mathrm{mt} \mathrm{ha}^{-1}$ ), China $\left(50.97 \mathrm{mt} \mathrm{ha}^{-1}\right)$, Egypt (36.08 $\left.\mathrm{mt} \mathrm{ha}^{-1}\right)$ and Turkey $\left(60.71 \mathrm{mt} \mathrm{ha}^{-1}\right)$ (FAO, 2018). Among the different reasons of such a low yield, the depletion of soil organic matter and vis-à-vis soil fertility is of prime importance.

Soil organic matter is a key factor in maintaining long-term soil fertility since it is the reservoir of metabolic energy, which drives soil biological processes

\footnotetext{
Department of Agroforestry and Environment, Faculty of Agriculture, Bangabandhu Sheikh Mujibur Rahman Agricultural University, Gazipur 1706, Bangladesh

2 Department of Entomology, Faculty of Agriculture, Bangabandhu Sheikh Mujibur Rahman Agricultural University, Gazipur 1706, Bangladesh

${ }^{3}$ Institute of Tropical Agriculture, Kyushu University, Fukuoka 819-0395, Japan

* Corresponding author (E-mail: abiar@bsmrau.edu.bd)
}

involved in nutrient availability. A good soil should have at least $2.5 \%$ organic matter but in Bangladesh, most of the soils have less than $1.5 \%$, and some soils even less than $1 \%$ organic matter (FRG, 2012). Further, the use of mineral fertilizers alone has been associated with increased soil acidity, nutrient imbalance and soil degradation. A comparable level of productivity can be achieved with the use of low level of mineral fertilizer combined with manures (Akande et al., 2010). Therefore, mixing organic and inorganic fertilizers could be a sound soil fertility management strategy. Cow dung is known to be effective in maintenance of adequate supply of organic matter in soil, with improvement in soil physical and chemical properties and enhanced crop performance. Meanwhile, the benefits of gliricidia leaf incorporation into the soil are well known, which results in increase of soil organic matter and nitrogen; improvement of soil physical characteristics, aeration and drainage. Furthermore, when the leaves are initially applied as a surface mulch used to control weeds, reduces surface soil erosion and soil temperature, and help conserve soil moisture (Kang et al., 1990). Gliricidia is native to the seasonally dry parts of Mexico and Central America and is now cultivated throughout the world as a result of domestication over many centuries. Gliricidia fresh leaf may be used as an alternative to cow dung.

Public anxiety has been growing, nowadays, about pesticides non-target effects on humans and other organisms. Many pests have devolved resistance to some of the most commonly-used pesticides. Since the tomato is eaten raw as salad, the quality of the fruits in terms of agrochemicals use is important to avoid health and environmental hazards. One pest-management alternative is the diversification of agricultural fields by 
establishing "polycultures" that include one or more different crop varieties or species within the same field, to more closely match the higher species richness typical of natural systems (Vandermeer, 1989).

Companion planting is a kind of poly culture, under which two species of plants are grown together that are acquainted to promote one another's growth. In addition, it might have repelling and/or intercepting effects on pests and pathogens and attract natural enemies or provide food for natural enemies. In principle, pests have direct negative effects on the crop, whereas natural enemies have direct negative effects on the pests, and thus have indirect positive effects on the crop (Letourneau et al., 2011). Both host-hiding and encouragement of natural enemies have the potential to depress pest populations and increase the abundance of beneficial insects (Schader et al., 2005), reducing the need for pesticide applications and increasing crop yields (Van Emden and Williams, 1974). Currently, pollination is thought to be one of the key ecosystem services, provided that humans depend on its association for food production, what prepares it a process with inseparable economic value (Hanley et al., 2015).

There are several plants, which are considered as excellent companions for tomato. Those plants may provide insecticidal properties to control and repel insect pests because of the pressure of rich source of bioactive chemicals. Among them, Basil (Ocimum basilicum), Nira (Allium ramosum) and Coriander (Coriandrum sativum) are beneficial for tomato. Culinary herbs have been reported to possess antioxidant activities that can deter insect pest (Yanishlieva et al., 2006). An attempt has therefore been made to compare the suitability of companion plant along with organic sources for tomato production in terms of productivity and pest management aspects in Bangladesh and investing the soil properties changes due to incorporation of gliricidia leaf into soil over traditional farming system.

\section{MATERIALS AND METHODS}

\section{Study site}

The study was conducted at the Bangabandhu Sheikh Mujibur Rahman Agricultural University research farm which is located at $24.00^{\circ} \mathrm{N}$ latitude and $90.25^{\circ} \mathrm{E}$ longitude (Hawlader and Mian, 1997) during the period from October 2016 to March 2017. It has an altitude of $8.4 \mathrm{~m}$ above the sea level (Hawlader and Mian, 1997) with average monthly rainfall between $0-82.63 \mathrm{~mm}$, average monthly temperature between $12.11-32.77^{\circ} \mathrm{C}$ and average monthly relative humidity between 80.5690.62\% during the experimentation (Meteorological Station, BSMRAU). The soil of the experimental field belongs to Orchrept suborder of USDA soil taxonomy locally termed as Salna series of Shallow Red-Brown Terrace soil (Haider, Marumoto and Azad, 1991) under the agro-ecological zone of Madhupur Tract (AEZ-28).

\section{Experimental design and treatments}

The experiment was arranged in a randomized com- plete block design (RCBD) with eight treatments replicated three times. Tomato (test crop) was grown along with Basil, Nira, Coriander as companion plants and gliricidia leaf and cow dung as manure.

The treatments were Gliricidia+Basil, Gliricidia + Nira, Gliricidia + Coriander, Gliricidia only, Cow dung + Basil, Cow dung + Nira, Cow dung + Coriander, and Cow dung only (Conventionl practice).

\section{Planting materials}

BARI Tomato-14 variety was used as test crop and the seeds of which were collected from the Horticulture Research Centre (HRC), Bangladesh Agricultural Research Institute (BARI), Gazipur. Locally cultivated Basil and Nira were purchased from Gazipur market. BARI dhania-1 was collected from Spices Research Centre (SRI), Bangladesh Agricultural Research Institute (BARI), Gazipur. The choice of Basil, Nira and Coriander as companion plants was made due to the characteristic strong smell of the essential oils that they contain.

\section{Land preparation, crop establishment and mainte- nance}

The site was disc ploughed as an initial step of land preparation. Land was then leveled using hand tools to provide a medium fine tilth for the better growth of tomato, basil, nira and coriander. The experimental area consisted of 24 plots having the plot size of $10 \mathrm{~m}^{2}$. There were eight treatments of which four were treated by gliricidia fresh leaf into the soil at the rate of $1 \mathrm{~kg} \mathrm{~m}^{-2}$ and another four treatments were applied with cow dung in soil at the rate of $1 \mathrm{~kg} \mathrm{~m}^{-2}$. Cow dung was added as organic source in soil for improving the soil fertility and comparing the efficiency of gliricidia leaf in improvement of soil fertility. Organic manures were applied two weeks before transplanting. The experimental plots were fertilized at the rate of $600 \mathrm{~kg}$ urea, $500 \mathrm{~kg}$ TSP, $300 \mathrm{~kg}$ MP per hectare. Total TSP and one third each of urea and MP were applied during the final land preparation and the rest of urea and MP were applied in two equal installments at 20 and 40 days after transplanting (Hussain et al., 2006). Each plot had four rows of tomato three each, with bordering companion plants but the control plot had four rows of tomato six each without any companion plants.

Tomato, basil and nira seedlings were raised in a seedbed at the beginning of the season at the nursery of the department of Agroforestry and Environment, BSMRAU. Thirty five (35) days old healthy, uniform tomato seedlings were planted at $60 \mathrm{~cm} \times 50 \mathrm{~cm}$ spacing. Basil and nira were planted by maintaining distance at 50 and $10 \mathrm{~cm}$, respectively. Transplanting was done at the afternoon. Coriander seeds were continuously sown in main field. Seedlings of coriander were thinned out at a distance of $5 \mathrm{~cm}$. Companion plants were grown at the border of each tomato plot. All agronomic practices (weeding, irrigation and drainage) were done during the study period as and when needed. Insect pests of tomato crop were expected to be suppressed by com- 
panion plants. Therefore, no insecticide was used throughout the study period for controlling the insect pests.

\section{Data collection for crop performance}

Five tomato plants from each plot were selected randomly and tagged for data collection. Number of clusters per plant was counted when tomato attained edible size. Fruit length and diameter were measured by using digital vernier caliper at harvest. Tomato fruits from each treatment were harvested by hand picking at the breaker stage for five times throughout the study period. At each harvest, fruits from each treatment were separately counted and later on weighed using a digital weighing balance. Fresh yield of tomato was determined by cumulative weight of fruits from each harvest and then converted to kg plant ${ }^{-1}$.

\section{Insect sampling and identification}

Collections of various insect groups were done fortnightly between November, 2016 and February, 2017 from the tomato plots. The insect sampling was carried out in the early hours of the day as insects are active and easily observed at early sunrise. The insects were collected by sweep nets and pitfall method depending on the type of insect. Each sample was consisted of 30 sweeps or 30 pitfalls encompassing each plot. The collected insects were brought from the experiment field to the Entomology Laboratory of BSMRAU for counting total abundance. The insects were killed by storage in a freezer for a few hours, then mounted on points and dried and morphotyped. Insects were identified and also grouped into pest, pollinator and predator. For identification, the specimens were compared with the specimens in a labeled collection and compared with pictures or descriptions.

To enlighten the pest management potentiality of basil, nira and coriander, it is necessary to evaluate abundance, richness and diversity. Abundance is usually measured as the number of individuals found per sample. Species Richness is the number of different species present in an area. Species diversity relates to the number of the different species and the number of individuals of each species within any one community. The formula for calculating Simpson's index is:

$$
\mathrm{D}=\frac{\sum \mathrm{n}_{i}\left(\mathrm{n}_{i}-1\right)}{\mathrm{N}(\mathrm{N}-1)}
$$

Where, $\mathrm{N}=$ the total number of all insects, $\mathrm{n}_{i}=$ the total numbers of insects of each individual species.

\section{Analysis of chemical properties of soil}

A composite sample of soil was taken randomly $(0-10 \mathrm{~cm})$ using soil auger before the commencement and after the experiment to determine the soil fertility status before and after experimentation. The soil was air dried, crushed, sieved and analyzed for chemical properties. Soil $\mathrm{pH}$ was measured by Glass Electrode $\mathrm{pH}$ meter method with soil- water ratio being maintained at 1:2.5 (McLean, 1982). At first organic carbon (\%) in soil sam- ple was determined by wet oxidation method and then it was converted into organic matter (\%) multiplying by 1.72 (Angers et al., 1999). Total nitrogen content of soil was determined by Kjeldahl Method following concentrated sulfuric acid digestion and steam distillation with $40 \% \mathrm{NaOH}$. The ammonia evolved was collected in a beaker containing $4 \%$ boric acid with an indicator composed of 95\% alcohol, methyl red and bromocresol green and was titrated against $0.02 \mathrm{~N} \mathrm{H}_{2} \mathrm{SO}_{4}$ as described by Jackson (1973). The amount of $\mathrm{N}$ was calculated using the following formula:

$$
\% \mathrm{~N}=14.007 \times \mathrm{N} \times \mathrm{f} \times(\mathrm{T}-\mathrm{B}) \times(100 / 10) \times(100 / \mathrm{Y})
$$

Where,

$1 \mathrm{~N} \mathrm{H}_{2} \mathrm{SO}_{4}$ standard solution $(1 \mathrm{ml})=14.007 \mathrm{~g} \mathrm{NH}_{4}^{+}-\mathrm{N}$

$\mathrm{T}=$ Sample titration (ml) value of standard $\mathrm{H}_{2} \mathrm{SO}_{4}$

$\mathrm{B}=$ Blank titration (ml) value of standard $\mathrm{H}_{2} \mathrm{SO}_{4}$

$\mathrm{N}=$ Strength of $\mathrm{H}_{2} \mathrm{SO}_{4}=0.02$

$\mathrm{Y}=$ Sample weight in gram (1 g)

10 = Quantity of digested extract taken for distillation (ml)

$100=$ Total digest amount $(\mathrm{ml})$

$100=$ Conversion factor for percentage

$\mathrm{F}=$ Titration accuracy factor $=1.02$

\section{Statistical analysis}

Data were subjected to Analysis of Variance (ANOVA) using Statistix 10 program following randomized complete block design. Treatment means that showed significant difference by $\mathrm{F}$ test were separated using least significant difference (LSD) test at $\mathrm{p} \leq 0.05$.

\section{RESULTS}

\section{Yield and yield contributing characteristics of tomato}

The effect of organic manure and companion plants on the number of clusters per plant $\left(\mathrm{F}_{7,14}=21.97, \mathrm{p}<\right.$ 0.001), number of fruits per plant $\left(\mathrm{F}_{7,14}=55.55, \mathrm{p}<0.001\right)$ and fruit weight per plant $\left(\mathrm{F}_{7,14}=94.86, \mathrm{p}<0.001\right)$ of tomato were significantly varied among the treatments except fruit length $\left(\mathrm{F}_{7,14}=4.60, \mathrm{p}>0.001\right)$ and fruit diameter $\left(\mathrm{F}_{7,14}=2.20, \mathrm{p}>0.001\right)$. (Table 1 )

\section{Insect pest}

There had a significant variation among the treatments in terms of insect pest abundance $\left(\mathrm{F}_{7,14}=141.59\right.$, $\mathrm{p}<0.001)$, richness $\left(\mathrm{F}_{7,14}=28.84, \mathrm{p}<0.001\right)$ and diversity $\left(\mathrm{F}_{7,14}=19.29, \mathrm{p}<0.001\right)$. The abundance, richness and diversity of the insect pests in different treatments varied from $10.3 \pm 0.88$ to $26.3 \pm 1.86,3.6 \pm 0.19$ to $8.0 \pm 0.29$ and $0.12 \pm 0.02$ to $0.24 \pm 0.03$, respectively (Table 2 ).

\section{Pollinator}

Marked variation was found in the abundance $\left(\mathrm{F}_{7}\right.$ $\left.{ }_{14}=46.67, \mathrm{p}<0.001\right)$, richness $\left(\mathrm{F}_{7,14}=74.69, \mathrm{p}<0.001\right)$ and diversity $\left(\mathrm{F}_{7,14}=172.06, \mathrm{p}<0.001\right)$ of the insect pollinators as influenced by different treatments. The abundance, richness and diversity of the pollinators varied from 
Table 1. Effect of organic manure and companion plant on yield and yield contributing characteristics of tomato

\begin{tabular}{|c|c|c|c|c|c|}
\hline Treatment & $\begin{array}{l}\text { Number of clusters/ } \\
\text { plant }\end{array}$ & $\begin{array}{l}\text { Number of fruits/ } \\
\text { plant }\end{array}$ & $\begin{array}{l}\text { Fruit length } \\
(\mathrm{mm})\end{array}$ & $\begin{array}{l}\text { Fruit diameter } \\
(\mathrm{mm})\end{array}$ & $\begin{array}{l}\text { Fruit weight/ plant } \\
\text { (kg) }\end{array}$ \\
\hline Gliricidia + Basil & $16.66 \mathrm{a}$ & $35.00 \mathrm{a}$ & $54.89 \mathrm{a}$ & $61.53 \mathrm{a}$ & $4.4 \mathrm{a}$ \\
\hline Gliricidia + Nira & $11.33 \mathrm{bc}$ & $26.00 \mathrm{~d}$ & $48.98 \mathrm{bc}$ & $57.70 \mathrm{ab}$ & $2.6 \mathrm{c}$ \\
\hline Gliricidia + Coriander & $13.33 \mathrm{~b}$ & $29.00 \mathrm{c}$ & $52.86 \mathrm{ab}$ & $57.46 \mathrm{ab}$ & $3.2 \mathrm{~b}$ \\
\hline Gliricidia only & $8.33 \mathrm{~d}$ & $22.66 \mathrm{e}$ & $47.00 \mathrm{c}$ & $53.79 \mathrm{~b}$ & $1.8 \mathrm{~d}$ \\
\hline Cow dung + Basil & $16.66 \mathrm{a}$ & $32.33 \mathrm{~b}$ & $51.79 \mathrm{ab}$ & $57.49 \mathrm{ab}$ & $3.9 \mathrm{a}$ \\
\hline Cow dung + Nira & $11.00 \mathrm{c}$ & $25.00 \mathrm{~d}$ & $47.40 \mathrm{c}$ & $54.18 \mathrm{~b}$ & $2.5 \mathrm{c}$ \\
\hline Cow dung + Coriander & $13.33 \mathrm{~b}$ & $28.33 \mathrm{c}$ & $50.20 \mathrm{bc}$ & $56.54 \mathrm{ab}$ & $2.9 \mathrm{bc}$ \\
\hline Cow dung only & $8.66 \mathrm{~d}$ & $21.00 \mathrm{e}$ & $46.53 \mathrm{c}$ & $52.05 \mathrm{~b}$ & $1.7 \mathrm{~d}$ \\
\hline
\end{tabular}

Means with common letter (s) in column of the table do not differ significantly at 5\% level by LSD.

Table 2. Average abundance, richness and diversity of insect pests in different treatments during the experimentation

\begin{tabular}{llll}
\hline \multicolumn{1}{c}{ Treatment } & Abundance & Richness & Diversity \\
\hline Gliricidia + Basil & $10.3( \pm 0.88) \mathrm{e}$ & $3.6( \pm 0.19) \mathrm{d}$ & $0.12( \pm 0.02) \mathrm{d}$ \\
Gliricidia + Nira & $15.0( \pm 0.58) \mathrm{c}$ & $6.3( \pm 0.44) \mathrm{b}$ & $0.19( \pm 0.01) \mathrm{bc}$ \\
Gliricidia + Coriander & $13.0( \pm 0.58) \mathrm{d}$ & $5.5( \pm 0.32) \mathrm{c}$ & $0.17( \pm 0.01) \mathrm{c}$ \\
Gliricidia only & $26.6( \pm 1.20) \mathrm{a}$ & $7.2( \pm 0.37) \mathrm{a}$ & $0.21( \pm 0.03) \mathrm{ab}$ \\
Cow dung + Basil & $12.0( \pm 0.58) \mathrm{d}$ & $4.2( \pm 0.38) \mathrm{d}$ & $0.14( \pm 0.01) \mathrm{d}$ \\
Cow dung + Nira & $17.0( \pm 0.58) \mathrm{b}$ & $6.2( \pm 0.27) \mathrm{bc}$ & $0.20( \pm 0.02) \mathrm{b}$ \\
Cow dung + Coriander & $14.6( \pm 0.33) \mathrm{c}$ & $6.0( \pm 0.52) \mathrm{bc}$ & $0.19( \pm 0.01) \mathrm{bc}$ \\
Cow dung only & $26.3( \pm 1.86) \mathrm{a}$ & $8.0( \pm 0.29) \mathrm{a}$ & $0.24( \pm 0.03) \mathrm{a}$ \\
\hline
\end{tabular}

Data expressed as mean ( \pm SE). Means per insect group are taken from 30 sweeps or 30 pitfalls per total collection. Means with common letter (s) in column of the table do not differ significantly at 5\% level by LSD.

Table 3. Average abundance, richness and diversity of pollinators in different treatments during the experimentation

\begin{tabular}{llll}
\hline \multicolumn{1}{c}{ Treatment } & Abundance & Richness & Diversity \\
\hline Gliricidia + Basil & $34.0( \pm 2.08) \mathrm{a}$ & $7.5( \pm 0.29) \mathrm{a}$ & $0.27( \pm 0.012) \mathrm{a}$ \\
Gliricidia + Nira & $25.0( \pm 1.73) \mathrm{de}$ & $5.7( \pm 0.15) \mathrm{de}$ & $0.22( \pm 0.012) \mathrm{d}$ \\
Gliricidia + Coriander & $29.0( \pm 2.08) \mathrm{bc}$ & $6.4( \pm 0.30) \mathrm{c}$ & $0.24( \pm 0.012) \mathrm{c}$ \\
Gliricidia only & $13.0( \pm 0.58) \mathrm{f}$ & $4.1( \pm 0.09) \mathrm{f}$ & $0.17( \pm 0.015) \mathrm{f}$ \\
Cow dung + Basil & $31.6( \pm 1.86) \mathrm{ab}$ & $6.9( \pm 0.10) \mathrm{b}$ & $0.25( \pm 0.009) \mathrm{b}$ \\
Cow dung + Nira & $22.6( \pm 1.76) \mathrm{e}$ & $5.3( \pm 0.17) \mathrm{e}$ & $0.20( \pm 0.012) \mathrm{e}$ \\
Cow dung + Coriander & $27.0( \pm 2.08) \mathrm{cd}$ & $5.9( \pm 0.07) \mathrm{d}$ & $0.22( \pm 0.012) \mathrm{d}$ \\
Cow dung only & $14.0( \pm 0.58) \mathrm{f}$ & $3.9( \pm 0.03) \mathrm{f}$ & $0.15( \pm 0.009) \mathrm{g}$
\end{tabular}

Data expressed as mean ( \pm SE). Means per insect group are taken from 30 sweeps or 30 pitfalls per total collection. Means with common letter (s) in column of the table do not differ significantly at 5\% level by LSD.

$13.0 \pm 0.58$ to $34.0 \pm 2.08,3.9 \pm 0.03$ to $7.5 \pm 0.29,0.15 \pm 0.009$ to $0.27 \pm 0.012$, respectively (Table 3 ).

\section{Predator}

A significant difference was recorded among the treatments in terms of abundance $\left(\mathrm{F}_{7,14}=38.04\right.$, $\mathrm{p}<0.001)$, richness $\left(\mathrm{F}_{7,14}=307.69, \mathrm{p}<0.001\right)$ and diversity $\left(\mathrm{F}_{7,14}=97.43, \mathrm{p}<0.001\right)$ of the predator insects. The abundance, richness and diversity of the pests varied from $8.0 \pm 1.53$ to $18.3 \pm 0.88,2.7 \pm 0.08$ to $6.7 \pm 0.15$, $0.09 \pm 0.006$ to $0.24 \pm 0.006$, respectively (Table 4 ).

\section{Soil chemical properties}

Soil $\mathrm{pH}$, organic carbon and total nitrogen were posi- tively influenced due to incorporation of gliricidia leaf and cow dung, although the variation was not distinct. After application, soil $\mathrm{pH}$, organic carbon and total nitrogen were increased by $6.27 \%, 5 \%$ and $10.87 \%$ in gliricidia leaf applied plots compared to cow dung applied treatment, respectively; while it was $7.71 \%, 10 \%$ and $6.52 \%$ higher over initial values for the corresponding parameters, respectively (Table 5).

\section{DISCUSSION}

As nitrogen level of gliricidia was higher than cow dung, length and diameter of tomato fruit were higher in gliricidia than cow dung treated plot with different com- 
Table 4. Average abundance, richness and diversity of predators in different treatments during the experimentation

\begin{tabular}{lcll}
\hline \multicolumn{1}{c}{ Treatment } & Abundance & Richness & Diversity \\
\hline Gliricidia + Basil & $18.3( \pm 0.88) \mathrm{a}$ & $6.7( \pm 0.15) \mathrm{a}$ & $0.24( \pm 0.006) \mathrm{a}$ \\
Gliricidia + Nira & $12.6( \pm 0.33) \mathrm{d}$ & $4.7( \pm 0.15) \mathrm{e}$ & $0.17( \pm 0.003) \mathrm{d}$ \\
Gliricidia + Coriander & $16.0( \pm 0.58) \mathrm{bc}$ & $5.8( \pm 0.06) \mathrm{c}$ & $0.21( \pm 0.010) \mathrm{b}$ \\
Gliricidia only & $8.5( \pm 0.29) \mathrm{f}$ & $2.9( \pm 0.03) \mathrm{f}$ & $0.11( \pm 0.003) \mathrm{f}$ \\
Cow dung + Basil & $16.3( \pm 0.88) \mathrm{b}$ & $6.0( \pm 0.08) \mathrm{b}$ & $0.22( \pm 0.007) \mathrm{b}$ \\
Cow dung + Nira & $10.6( \pm 0.33) \mathrm{e}$ & $4.5( \pm 0.14) \mathrm{e}$ & $0.15( \pm 0.003) \mathrm{e}$ \\
Cow dung + Coriander & $14.3( \pm 0.33) \mathrm{cd}$ & $5.4( \pm 0.07) \mathrm{d}$ & $0.19( \pm 0.007) \mathrm{c}$ \\
Cow dung only & $8.0( \pm 1.53) \mathrm{f}$ & $2.7( \pm 0.08) \mathrm{f}$ & $0.099( \pm 0.006) \mathrm{g}$
\end{tabular}

Data expressed as mean \pm SE. Means per insect group are taken from 30 sweeps or 30 pitfalls per total collection. Means with common letter (s) in column of the table do not differ significantly at 5\% level by LSD.

Table 5. Changing of soil chemical properties after harvesting of tomato in cow dung and gliricidia leaf applied plots compared to initial soil

\begin{tabular}{lccr}
\hline \multirow{2}{*}{ Soil properties } & Initial soil & \multicolumn{2}{c}{ After harvesting tomato } \\
\cline { 3 - 4 } pH & & $6.01(7.7)^{z}$ & $5.93(6.3)$ \\
\% of Organic carbon & 2.58 & $2.20(10.0)$ & $2.10(5.0)$ \\
\% of Total nitrogen & 0.092 & $0.098(6.52)$ & $0.102(10.9)$ \\
\hline
\end{tabular}

${ }^{z} \%$ of changing from initial soil to after harvesting tomato

panion plants. Pereira et al. (2015) showed that fruit length, basal circumference and apical circumference of bell peppers were higher in intercropping with basil than in single-cropping system. It was further stated that fruit length, basal circumference and apical circumference of bell peppers were higher in 'With bees' than 'Without bees' greenhouse compartment. Pollinator abundance in Gliricidia + Basil plot is higher than all other treatments. It may ensure the correspondence number of fruits per plant which is positively correlated with number of clusters per plant.

Due to higher fruit length and diameter of tomato, the fruit weight per plant was significantly higher in Gliricidia + Basil than other treatments. Pandey and Rai (2007) mentioned that gliricidia leaves decompose quickly and release maximum nitrogen within 15 days and the remaining part in two months in both surface applied as well as soil incorporated conditions. Nitrogen received quickly might increase in the amount of some cell structures such as- growth of the wall, thickness of the cell wall and amount of solids, which ultimately increased the fruit weight per plant. Pereira et al. (2015) showed that pulp weight of bell peppers was higher in intercropping with basil than in single-cropping system.

The weight, size of the fruits and the number of seeds has also been found to be correlated to the amount of pollen deposited on the stigma (Serrano and Guerra-Sanz, 2006). Auxin, which is produced in pollen and the endosperm and the embryo of developing seeds, are involved in the regulation of fruit development, in that it generates the initial stimulus for fruit growth (Taiz and Zeiger, 2010). Thus, flowers better pollinated by bees can develop fruits with characteristics different from those of fruits produced by self-pollination as well as the width and weight of tomato were enhanced by the pollinators.

Quee et al. (2017) claimed that gliricidia leaves mulch has the possibility of conferring higher crop growth and yields as well as decreased weed growth in maize production. Application of gliricidia leaves in combination with chemical fertilizers has given tremendous yield improvements in both tomato and chili than coir dust, cow dung and rice straw (Kendaragama,1999). Application of leguminous (e.g. gliricidia) green leaf manures and tree leaf extracts giving in the form of seed soaking and foliar sprays will increase the growth, yield, quality and economics of bhendi (Anbukkarasi and Sadasakthi, 2017).

Companion plants have great influence on pest abundance, richness and diversity. Beizhou et al. (2011) intercropped companion plant in Pear orchards with three aromatic plants: summer savory, ageratum, basil and got significantly lower population of major pests, especially Aphis citricola, as compared with natural grasses or clean tillage. Again, Basedow, Hua and Aggarwal (2006) reported that basil and summer savory intercropped with Vicia faba in a wind tunnel, greenhouse or field decreased the Aphis fabae population significantly. The strong aphid-repelling action of the Allium spp. (e.g. nira) is well established. It could be connected with the presence of high-sulfur compounds (94\%). These compounds are known for their protective potential against storage insects (Ben-Issa et al., 2017). Coriander repelled aphids, spider mites and potato beetles in potato (Kianmate and Ranamukhaarachchi, 2007).

Basil was found to attract a great richness and abundance of pollinators, which makes it suitable to enhance pollinator conservation and management in agricultural 
environments. The floral resources provided by basil clearly benefited pollinator abundance and richness; however, while the primary objective of such practice was to favor pollinator and pollination. This strategy has the potential to provide secondary benefits to the farm and the surrounding landscape by enhancing overall biodiversity and ecosystem services (Wratten et al., 2012). Majority of the hymenopteran pollinators were recorded on coriander, mustard and radish plants; whereas, more dipteran pollinators were observed on coriander, broad bean, lucerne and mustard (Ahmad, 2005).

Conserving of beneficial insects may be increased due to inclusion of floral resources where nectar and pollen is fed by functional groups including pest natural enemies (Balzan et al., 2014). In a pear orchard ecosystem, Beizhou et al. (2011) used aromatic plants such as summer savory, ageratum and basil between pear tree rows enhanced the activity of the lady bird beetle and reduced the incidence of Aphis citricola. In New Zealand, for example, coriander as a companion plant intercropped with cabbage has been shown to attract adult hoverflies and decrease the aphid number only early in the season (Ben-Issa et al., 2017).

The soil chemical properties were changed owing to chemical composition of cow dung and gliricidia. Cow dung consist of the following chemical composition $1.60 \% \mathrm{~N}, 0.70 \% \mathrm{P}, 0.53 \% \mathrm{~K}, 0.91 \% \mathrm{Mg}, 2.71 \% \mathrm{Ca}, 0.50 \%$ $\mathrm{Na}$ and $56.8 \%$ organic matter (Onwudike, 2010). The chemical composition of gliricidia leaves are of $4.16 \% \mathrm{~N}$, $0.40 \% \mathrm{P}, 1.12 \% \mathrm{~K}, 0.58 \% \mathrm{Mg}, 0.67 \% \mathrm{Ca}, 29.73 \%$ organic carbon and $51.79 \%$ organic matter (Falana et al., 2017). Calcium and organic matter were higher in cow dung than gliricidia. But nitrogen content was higher in gliricidia than cow dung. That is why, gliricidia treated plot showed higher nitrogen and cow dung showed higher $\mathrm{pH}$, organic matter than cow dung and gliricidia, respectively.

\section{CONCLUSIONS}

Based on the findings of the study, it may be concluded that performance of tomato in association with three companion plants viz. basil, nira and coriander was better in all aspects as compared to monoculture. Tomato showed better performance in terms of fruit yield, soil chemical properties, insect pest suppression as well as pollinators and predators attraction when grown along with basil as companion plant followed by coriander and nira.

\section{AUTHOR CONTRIBUTIONS}

Mahfujul Islam BHUIYA, performed the research, collected data, analyzed the data and wrote the first draft of manuscript.

Md. Abiar RAHMAN, formulated and designed the idea of the study and supervised the research. Analysed the data and helped in preparing the manuscript.

Md. Ruhul AMIN, identified the insects and inspected final data. Analysed data related to insects.
Md. Main Uddin MIAH and Satya Ranjan SAHA Helped in field data collection and manuscript check.

Ikuo MIYAJIMA provided suggestions in designing the research and comments on the manuscript.

However, all authors assisted in editing the manuscript and approved the final version.

\section{ACKNOWLEDGEMENTS}

This study was sponsored by Bangabandhu Sheikh Mujibur Rahman Agricultural University (BSMRAU). We are thankful to the members of Department of Agroforestry and Environment, BSMRAU for helping during the field study. We are highly grateful to Horticulture Research Centre (HRC), Spices Research Centre (SRI) of Bangladesh Agricultural Research Institute (BARI).

\section{REFERENCES}

Ahmad, A. A. 2005 Hymenopterous and dipterous pollinators diversity on various flowering plants in Riyadh, Saudi Arabia. Assiut J. Agric. Sci., 36: 69-83

Akande, M. O., F. I. Oluwatoyinbo, E. A. Makinde, A. S. Adepoju and I. S. Adepoju 2010 Response of okra to organic and inorganic fertilization. Nature and Science, 8: 261-266

Anbukkarasi, V. and A. Sadasakthi 2017 Effect of leguminous green leaf manures and leaf extract on growth, yield, quality and economics of bhendi (Abelmoschus esculentus L. Moench) cV. Arka Anamika. Indian J. Agr. Res., 51: 9-16

Angers, D. A., L. M. Edwards, D. A. Angers, J. B. Sanderson and N. Bissonnette 1999 Soil organic matter quality and aggregate stability under eight potato cropping sequences in a fine sandy loam of Prince Edward Island. Canadian J. Soil Sci., 79: 411-417

Balzan, M. V., G. Bocci and A. C. Moonen 2014 Augmenting flower trait diversity in wildflower strips to optimise the conservation of arthropod functional groups for multiple agroecosystem services. J. Insect. Conserv., 18: 713-728

Bangladesh Bureau of Statistics, 2017 Table 2.1.1: Area, Yield Rate and Production of Crops 2013-14 to 2015-16.Yearbook of agricultural statistics-2016 (28 $8^{\text {th }}$ Series). Statistics and Informatics Division, Ministry of Planning, Government of the People's Republic of Bangladesh

Basedow, T., L. Hua and N. Aggarwal 2006 The infestation of Vicia faba L. (Fabaceae) by Aphis fabae (Scop.) (Homoptera: Aphididae) under the influence of Lamiaceae (Ocimum basilicum L. and Satureja hortensis L.). J. Pest Sci., 79: 149

Beizhou, S., Z. Jie, H. Jinghui, W. Hongying, K. Yun and Y. Yuncong 2011 Temporal dynamics of the arthropod community in pear orchards intercropped with aromatic plants. Pest Manage. Sci., 67: 1107-1114

Ben-Issa, R., L. Gomez and H. Gautier 2017 Companion plants for aphid pest management. Insects, 8: 112

Falana, A. R., F. B. Musa, O. A. Ogidan and A. F. Aderounmu 2017 Effect of Gliricidia sepium leaves and cow dung on the growth of Khaya senegalensis A. Juss. seedlings. J. For. Res. Manag., 14: $37-48$.

Food and Agriculture Organization of United Nations, 2018 FAOSTAT Crops. Retrieved May, 2018 from http://faostat.fao. org/site/291/default.aspx

FRG, 2012 Fertilizer recommendation guide. Bangladesh Agricultural Research Council (BARC), Farmgate, Dhaka: 58

Haider, J., T. Marumoto and A. K. Azad 1991 Estimation of microbial biomass carbon and nitrogen in Bangladesh soils. Soil Sci. Plant Nutr., 37: 591-599

Hanley, N., T. D. Breeze, C. Ellis and D. Goulson 2015 Measuring the economic value of pollination services: Principles, evidence and knowledge gaps. Ecosyst. Serv., 14: 124-132 
Hawlader, M. S. H. and M. A. K. Mian 1997 Self-incompatibility studies in local cultivars of radish (Raphanus sativus L.) grown in Bangladesh. Euphytica, 96: 311-315

Hsu, Y. M., C. H. Lai, C. Y. Chang, C. T. Fan, C. T. Chen and C. H. Wu 2008 Characterizing the lipid-lowering effects and antioxidant mechanisms of tomato paste. Biosci. Biotechnol. Biochem., 72: $677-685$

Hussain, M. S., S. E. El-Sherbeny, M. Y. Khalil, N. Y. Naguib and S. M. Aly 2006 Growth characters and chemical constituents of Dracocepha lummoldavica L. plants in relation to compost fertilizer and planting distance. Sci. Hortic.-Amsterdam, 108: 322331

Jackson, M. L. 1973 Soil Chemical Analysis. Prentice-Hall of India, New Delhi, pp. 134-226

Kang, B. T., L. Reynolds and A. N. Atta-Krah 1990 Advances in Agronomy, Academic Press, pp. 315-359

Kendaragama, K. M. A. 1999 Response of tomato and chilli to application of organic materials on an alfisol. Annals Sri Lanka Dept. Agric., 1: 108-113

Kianmate, S. and S. L. Ranamukhaarachchi 2007 Pest repellent plants for management of insect pests of Chinese kale, Brassica oleracea L. Int. J. Agric. Biol., 9: 64-67

Letourneau, D. K., I. Armbrecht, B. S. Rivera, J. M. Lerma, E. J. Carmona, M. C. Daza, S. Escobar, V. Galindo, C. Gutierrez, S. D. Lopez, 'et al..' 2011 Does plant diversity benefit agroecosystems? A synthetic review. Ecol. Appl., 21: 9-21

McLean, E. O. 1982 Methods of soil analysis. Part 2. Chemical and microbiological properties, American Society of Agronomy, Soil Science Society of America, Madison, pp. 199-224

Onwudike, S. U. 2010 Effectiveness of cow dung and mineral fertilizer on soil properties, nutrient uptake and yield of sweet potato (Ipomoea batatas) in Southeastern Nigeria. Asian J. Agric. Res., 4: 148-154
Pandey, C. B. and R. B. Rai 2007 Nitrogen cycling in gliricidia (Gliricidia sepium) alley cropping in humid tropics. Trop. Ecol., 48(1): 87-97

Pereira, A. L. C., T. C. Taques, J. O. Valim, A. P. Madureira and W. G. Campos 2015 The management of bee communities by intercropping with flowering basil (Ocimum basilicum) enhances pollination and yield of bell pepper (Capsicum annuum). J. Insect Conserv., 19: 479-486

Quee, D. D., A. Mansaray, S. M. Kanneh, P. J. Kamanda, A. R. Conteh, E. J. Ndoko and K. Serry 2017 Effect of Gliricidia sepium leaf mulch on weed growth and productivity of maize (Zea mays L.) in Southern Sierra Leone. Int. J. Agric. For., 7(2): 35-41

Schader, C., J. G. Zaller and U. Köpke 2005 Cotton-basil intercropping: Effects on pests, yields and economical parameters in an organic field in Fayoum. Egypt. Biol. Agric. Hortic., 23: 59-72

Serrano, A. R. and J. M. Guerra-Sanz 2006 Quality fruit improvement in sweet pepper culture by bumble bee pollination. Sci. Hortic., 110(2): 160-166

Taiz, L. and E. Zeiger 2010 Plant physiology, 5th ed. Sinauer Associates Inc., Sunderland.

Van Emden, H. F. and G. F. Williams 1974 Insect stability and diversity in agro-ecosystems. Annu. Rev Entomol., 19(1): 455475

Vandermeer, J. H. 1989 The ecology of intercropping, $1^{\text {st }}$ ed. Cambridge University Press, pp. 176-188

Wratten, S. D., M. Gillespie, A. Decourtye, E. Mader and N. Desneux 2012 Pollinator habitat enhancement: Benefits to other ecosystem services. Agric. Ecosyst. Env., 159: 112-122

Yanishlieva, N. V., E. Marinova and J. Pokorný 2006 Natural antioxidants from herbs and spices. Eur. J. Lipid Sci. Tech. 108(9): 776-793 
